\title{
APLIKASI PRA PENDINGINAN TERHADAP DAYA SIMPAN BUAH TOMAT (Solanum lycopersicum L.) \\ (Pre-cooling Application to Shelflife Tomatos Fruit (Solanum lycopersicum L.))
}

\author{
Ngadiono $^{2)}$ Muliansyah ${ }^{1)}$, Saleh, M. ${ }^{2)}$ \\ ${ }^{1)}$ Program Studi Teknologi Industri Pertanian, Jurusan Budidaya Pertanian, Fakultas Pertanian, UPR, \\ ${ }^{2)}$ Program Studi Agroteknologi, Jurusan Budidaya Pertanian, Fakultas Pertanian, UPR, \\ Email : muliansyah_nihin@yahoo.co.id
}

Diterima : 23/03/2018

Disetujui : 29/10/2018

\begin{abstract}
The objectives of this study were: To know the influence of the pre-cooling duration on the quality tomato fruit, and the influence of the pre-cooling duration on the tomato fruit shelflife. Implementation of this research activity conducted for one month starting in March-April 2017, which is located in Laboratory of Department of Agriculture Cultivation, Faculty of Agriculture, University of Palangkaraya, Central Kalimantan Province. This study used a Single Randomized Complete Random (RAL) design with a pre-cooling treatment time consisting of 4 (four) treatments ie $\mathrm{P} 0=$ Without precooling, P15 = Pre-cooling 15 minutes, P30 = Pre-cooling 30 minutes, and P45 = Pre-cooling 45 minutes. The observed variables were water content, vitamin $\mathrm{C}$, weight loss, total acid, and total dissolved solids. The results showed that pre-cooling P15 was able to provide a good shelf life of up to 17 days. A 15-minute pre-cooling treatment is the best result in minimizing moisture evaporation. Vitamin $\mathrm{C}$ has increased in days 5 th, 7 th, and 9 th. The highest weight loss was in pre-cooling 30 minutes 7 days with a value of $5.47 \%$, indicating an increased weight shrinkage value in a 15 -minute pre-cooling treatment. The highest total acid value on 3 day was pre-cooling treatment of 15 minutes with a value of $5.28 \%$, indicating the total acid value during storage increased and decreased. The total content of dissolved solids did not differ significantly between the pre-cooling treatment of tomatoes. Pre-cooling treatment can extend the shelf life.
\end{abstract}

Keywords: Tomato fruit, Pre-coling, quality, shelf life

\begin{abstract}
ABSTRAK
Tujuan dari penelitian ini adalah mengetahui pengaruh lama pra-pendinginan terhadap mutu buah tomat, dan mengetahui pengaruh lama pra-pendinginan terhadap daya simpan buah tomat. Pelaksanaan kegiatan penelitian ini dilaksanakan selama satu bulan dimulai pada bulan Maret-April 2017, yang bertempat di Laboratorium Jurusan Budidaya Pertanian, Fakultas Pertanian, Universitas Palangka Raya, Provinsi Kalimantan Tengah. Penelitian ini menggunakan Rancangan Acak Lengkap (RAL) faktor tunggal dengan perlakuan lama waktu pra-pendinginan yang terdiri dari 4 (empat) perlakuan yaitu $\mathrm{P} 0=$ Tanpa pra-pendinginan, $\mathrm{P} 15$ = Pra-pendinginan 15 menit, $\mathrm{P} 30$ = Pra-pendinginan 30 menit, dan P45 = Pra-pendinginan 45 menit. Variabel yang diamati yaitu kadar air, vitamin C, susut bobot, total asam, dan total padatan terlarut. Hasil penelitian menunjukan bahwa pra-pendinginan P15 mampu memberi masa simpan yang baik sampai 17 hari. Perlakuan pra-pendinginan 15 menit merupakan hasil terbaik dalam memperkecil penguapan kadar air. Vitamin $\mathrm{C}$ mengalami peningkatan pada hari ke-5, 7, dan ke-9. Susut bobot tertinggi terdapat pada pra-pendinginan 30 menit hari ke7 dengan nilai 5,47\%, hal ini menunjukan nilai susut bobot meningkat di perlakuan pra-pendinginan 15 menit. Nilai total asam tertinggi pada hari ke-3 yaitu perlakuan pra-pendinginan 15 menit dengan nilai $5,28 \%$, hal ini menunjukan nilai total asam selama penyimpanan mengalami kenaikan dan penurunan.
\end{abstract}


Kandungan total padatan terlarut tidak berbeda nyata antara perlakuan pra-pendinginan buah tomat.Perlakuan pra-pendinginan dapat memperpanjangmasa simpan.

Kata kunci : buah tomat, pra-pendinginan, mutu, masa simpan

\section{PENDAHULUAN}

Tomat merupakan salah satu produk hortikultura yang banyak diperlukan untuk kebutuhan sehari-hari. Tomat mudah mengalami kerusakan setelah pemanenan, baik kerusakan fisik, mekanis maupun mikrobiologis, padahal sebagian besar dari produk tersebut dibutuhkan dalam keadaan segar Pantastico, (1989) dan Winarno dan Aman, (1991). Oleh karena itu, penanganan pasca panen yang memadai sangat diperlukan untuk mempertahankan kesegaran, mencegah susut dan kerusakan tomat.

Kehilangan air dari produk hortikultura saat berada pada pohon tidak masalah karena masih dapat digantikan atau diimbangi oleh laju pengambilan air oleh tanaman. Berbeda dengan produk yang telah dipanen kehilangan air tersebut tidak dapat digantikan, karena produk tidak dapat mengambil air dari lingkungnnya. Demikian juga kehilangan substrat juga tidak dapat digantikan sehinga menyebabkan perubahan kualitas dari produk yang telah dipanen atau dikenal sebagai kemunduran kualitas dari produk, tetapi pada suatu keadaan perubahan tersebut justru meningkatkan kualitas produk tersebut

Penyimpanan buah tomat umumnya masih terbatas pada penyimpanan dingin dengan berbagai variasi perlakuan. Akan tetapi sebelum dilakukan penyimpanan dingin sangat dibutuhkan penurunan suhu awal/panas lapang. Peningkatan panas ini disebabkan terjadinya respirasi mendadak karena komoditi mengalami stres pada awal pemanenan. Penurunan suhu awal/panas lapang dapat dilakukan dengan cara pra-pendinginan. Cahyaningsih, (2002) menyatakan bahwa pra-pendinginan diperlukan untuk menghilangkan kotoran dan debu yang menempel pada buah dan untuk menurunkan suhu lapang sehingga buah nantinya tidak cepat mengkerut dan busuk. Pra-pendinginan juga dapat memperlambat laju penurunan kualitas buah. Pada umumnya metode yang digunakan adalah metode pendinginan es. Metode ini memanfaatkan sifat-sifat es yang dapat menyerap panas, pendinginan dengan es juga sangat menguntungkan petani karena harganya murah. Menurut Kader, (1992), Wills et.al. (1998) dan Winarno, (2002) untuk memelihara mutu dan memperpanjang masa simpan, sangat penting dilakukan pendinginan produk secara cepat. Pendinginan dengan cara prapendinginan dapat dilakukan dengan cara air cooling (pendingnan dengan udara), hydro cooling (pendinginan dengan air) dan vacum cooling (pendinginan dengan ruang vakum).

Penanganan pascapanen yang kurang tepat dan cepat akan menyebabkan besarnya kerusakan pada produk-produk tersebut. Salah satu penanganan pascapanen pertama (tepat setelah pemetikan), yang dapat diupayakan adalah pencucian (washing) dan prapendinginan (pra-pendinginan).

Pra-pendinginan merupakan salah satu mata rantai pascapanen yang sangat penting di Indonesia. Pra-pendinginan bertujuan untuk menghilangkan panas lapang (field heat) dan suhu yang tinggi pada komoditas holtikultura sesegera dan secepat mungkin, mempertahankan kesegaran, sertamengurangi beban pendinginan. Selanjutnya prapendinginan dilakukan segera setelah panen dan dengan laju yang secepat mungkin.

\section{BAHAN DAN METODE}

\section{Rancangan dan Model}

Penelitian ini menggunakan Rancangan Acak Lengkap (RAL) faktor tunggal dengan perlakuan lama waktu pra-pendinginnan yang terdiri dari 4 (empat) perlakuan yaitu sebagai berikut: $\mathrm{P} 0=$ Tanpa pra-pendinginan, $\mathrm{P} 15=$ Prapendinginan 15 menit, $\mathrm{P} 30=$ Pra-pendinginan 30 menit, dan P45 = Pra-pendinginan 45 menit. Dalam penelitian terdapat 4 (empat) perlakuan, yang diulang sebanyak 6 (enam) kali ulangan sehingga terdapat 24 satuan percobaan. 


\section{Pelaksanaan Percobaan}

Pelaksanaan percobaan ini terdiri dari persiapan buah tomat, sortir, pengangkutan, perlakuan, analisis awal, penyimpanan, pengamatan, dan analisis.

\section{Persiapan Buah Tomat}

Mempersiapkan alat dan bahan buah tomat. Buah tomat yang diperlukan, 24 buah setiap perlakuan yaitu tanpa pra-pendinginan, pra-pendinginan 15 menit, pra-pendinginan 30 menit, dan pra-pendinginan 45 menit sehingga total buah yang diperlukan berjumah 96 buah tomat.

\section{Sortir Buah Tomat}

Buah tomat disortasi, tujuan dari sortasi ini adalah untuk menyeleksi dan memisahkan buah tomat yang baik dan buah tomat rusak.

\section{Perlakuan}

Perlakuan tanpa pra-pendinginan dan perlakuan pra-pendingin dengan lama sesuai perlakuan, untuk pra-pendinginan 15 menit yaitu dengan menggunakan es dan ditambahkan dengan air bersih secukupnya, dengan waktu 15 menit, pra-pendinginan 30 menit selama 30 menit, dan pra-pendinginan 45 menit selama 45 menit masa perendamannya. Kisaran suhu pada masing-masing box yaitu $15^{\circ} \mathrm{C}$.

\section{Pengamatan}

Sebelum buah tomat diberi perlakuan dilakukan pengacakan buah tomat untuk dijadikan sampel yang akan diamati serta dianalisis, baik untuk analisis awal dan pada pengamatan di Laboratorium diantaranya penimbangan untuk mengetahui berat awal, kandungan vitamin $\mathrm{C}$, kadar air, total asam, dan total padatan terlarut.

Pengamatan yang dilakukan pada hari ke $0,3,5,7,9$, dan 11 .

\section{Analisis Data}

Analisis data dilakukan dengan menggunakan analisis ragam uji $\mathrm{F}$ pada taraf $5 \%$ dan $1 \%$. Data dari hasil pengamatan tersebut kemudian diuji secara statistik menggunakan metode Duncan, dan dibantu dengan aplikasi SPSS

\section{HASIL DAN PEMBAHASAN}

\begin{abstract}
Kadar Air (\%)
Berdasarkan analisis ragam kadar air pada buah tomat selama masa simpan menunjukan bahwa perlakuan pra-pendinginan buah tomat mengalami peningkatan dan penurunan. Dimana semakin meningkatnya suhu dan lama penyimpanan akan memberi perbedaan setiap perlakuan, hasil analisis sidik ragam kadar air pada hari ke-1, 5, dan 7 menunjkan bahwa perlakuan pra-pendinginan setiap perlakuan berbeda nyata dapat dilihat pada Tabel 1 .
\end{abstract}

Tabel 1. Nilai Persentase Pengamatan Kadar Air (\%) Buah Tomat.

\begin{tabular}{cccccccccc}
\hline \multirow{2}{*}{ Perlakuan $^{(\mathrm{x})}$} & \multicolumn{8}{c}{ Pengamatan Kadar Air \%(Hari) } \\
\cline { 2 - 10 } & 1 & 3 & 5 & 7 & 9 & 11 & 13 & 15 & 17 \\
\hline P0 & $92,53^{\mathrm{a}}$ & 95,00 & $94,72^{\mathrm{a}}$ & $93,95^{\mathrm{a}}$ & 94,87 & 94,78 & & & \\
\hline P15 & $95,07^{\mathrm{d}}$ & 95,00 & $94,46^{\mathrm{a}}$ & $94,55^{\mathrm{ab}}$ & 95,21 & 95,35 & 94,76 & 94,84 & 95,48 \\
\hline P30 & $94,45^{\mathrm{c}}$ & 95,26 & $95,40^{\mathrm{b}}$ & $95,17^{\mathrm{b}}$ & & & & & \\
\hline P45 & $93,66^{\mathrm{b}}$ & 94,89 & $94,79^{\mathrm{a}}$ & & & & & & \\
\hline
\end{tabular}

Keterangan :

(x) $\mathrm{P} 0=$ Tanpa pra-pendinginan, $\mathrm{P} 15=$ Pra-pendinginan 15 menit, $\mathrm{P} 30=$ Pra-pendinginan 30 menit, dan P45= Pra-pendinginan 45 menit.Superscript yang diikuti oleh huruf yang sama menunjukkan tidak berbeda nyata, dimana pada baris yang kosong pada Tabel 1 ini buah tomat telah membusuk dan tidak dapat diamati atau dianalisis 
Berdasarkan hasil uji nilai tengah, seperti yang terlihat pada Tabel 1. Dapat diketahui bahwa, pada hari ke-1 setiap perlakuan berbeda nyata. Perbedaan terlihat kembali pada hari ke5 disetiap perlakuan, dimana pra-pendinginan 30 menit berbeda nyata dengan tanpa prapendinginan, pra-pendinginan 15 menit dan pra-pendinginan 45 menit, namun dari perlakuan tanpa pra-pendinginan, prapendinginan 15 menit dan pra-pendinginan 45 menit tidak berbeda nyata. Hasil pengamatan pada pra-pendinginan 30 menit menunjukan kadar air yang paling tinggi. Pengamatan hari ke-7 menunjukan pebedaan antara perlakuan tanpa pra-pendinginan dengan pra-pendinginan 30 menit berbeda nyata, namun tanpa prapendinginan tidak berbeda nyata dengan prapendinginan 15 menit dan pra-pendinginan 15 menit tidak berbeda nyata dengan prapendinginan 30 menit. Hal ini menunjukan nilai kadar air selama penyimpanan dari hari ke-1 sampai ke-17 mengalami kenaikan dan penurunan. Setiap kenaikan pra-pendinginan dalam penyimpanan nilainya pun semakin rendah dan setiap penurunan pra-pendinginan dalam masa penyimpanan nilaipun semakin tinggi. Dengan adanya nilai kadar air yang berbeda pada setiap penyimpanan dengan perlakuan pra-pendinginan ini menunjukan pula semakin tinggi atau rendahnya pra-pendinginan memiliki nilai yang berbeda. Artinya dengan semakin lama pra-pendinginan maka akan mempengaruhi penurunan buah tomat dalam masa simpan. Berdasarkan analisis dari masingmasing perlakuan pra-pendinginan dalam masa simpan, nilai tertinggi dalam masa simpan terdapat pada suhu $15^{0} \mathrm{C}$ dengan lama penyimpanan 17 hari. Namun hal ini menunjukan nilai kadar air selama penyimpanan dari hari ke-1 sampai ke-17 mengalami kenaikan dan penurunan.

\section{Vitamin C (mg/100g)}

Vitamin $\mathrm{C}$ merupakan mikro-nutrien yang dibutuhkan tubuh manusia agar semua metabolisme tubuh tetap berlangsung. Vitamin $\mathrm{C}$ merupakan vitamin yang larut dalam air dan hampir terdapat pada semua sayuran dan buahbuahan. Tomat merupakan salah satu buah yang memiliki kandungan vitamin $\mathrm{C}$ tinggi, selain itu buah tomat memiliki asam-asam organik seperti asamsitrat, asam malat, asam asetat, asam format, asam laktat, dan asam galaktonat. Selama masa penyimpanan, kandungan vitamin $\mathrm{C}$ buah dari hasil sidik ragam menunjukkan perlakuan pra-pendinginan dan lama penyimpanan berbeda nyata pada hari ke-5 dan ke-7. Akan tetapi lama penyimpanan berpengaruh terhadap perubahan vitamin $\mathrm{C}$ buah tomat dapat dilihat pada Tabel 2

Tabel 2. Nilai Pengamatan Vitamin C(mg/100g) Buah Tomat.

\begin{tabular}{cccccccccc}
\hline \multirow{2}{*}{ Perlakuan $^{(\mathrm{x})}$} & \multicolumn{8}{c}{ Pengamatan Vitamin C mg/100g (Hari) } \\
& \multicolumn{1}{c}{1} & 3 & 5 & 7 & 9 & 11 & 13 & 15 & 17 \\
\hline P0 & 0.01 & 0.00 & $0.01^{\mathrm{b}}$ & $0.01^{\mathrm{b}}$ & 0.03 & .005 & & & \\
\hline P15 & 0.01 & 0.01 & $0.01^{\mathrm{b}}$ & $0.00^{\mathrm{a}}$ & 0.03 & .004 & .004 & .004 & .004 \\
\hline P30 & 0.01 & 0.01 & $0.00^{\mathrm{a}}$ & $0.00^{\mathrm{ab}}$ & & & & & \\
\hline P45 & 0.01 & 0.01 & $0.00^{\mathrm{a}}$ & & & & & & \\
\hline
\end{tabular}

Keterangan :

(x) $\mathrm{P} 0=$ Tanpa pra-pendinginan, $\mathrm{P} 15=$ Pra-pendinginan 15 menit, $\mathrm{P} 30=$ Pra-pendinginan 30 menit, dan P45= Pra-pendinginan 45 menit. Superscript yang diikuti oleh huruf yang sama menunjukkan tidak berbeda nyata, dimana pada baris yang kosong pada Tabel 2 ini buah tomat telah membusuk dan tidak dapat diamati atau dianalisis. 
Berdasarkan uji
menunjukkan bahwa perlakuan prapendinginan, setiap perlakuan berbeda nyata terhadap kandungan vitamin $\mathrm{C}$ buah tomat. Kandungan vitamin $\mathrm{C}$ buah toman pada hari ke5 perlakuan pra-pendinginan 15 menit berbeda nyata dengan perlakuan pra-pendinginan 30 menit, pra-pendinginan 45 menit dan tidak berbeda nyata dengan tanpa pra-pendinginan. Sedangkan hasil dari pengamatan hari ke-7 menunjukan berbeda nyata antara tanpa prapendinginan dengan pra-pendinginan 15 menit serta tidak berbeda nyata antara perlauan prapendinginan 15 menit dengan pra-pendinginan 30 menit. Hasil pengamatan vitamin $\mathrm{C}$ pada perlakuan pra-pendinginan 15 menit ini setiap harinya ada peningkatan kecuali hari ke-7 ada penurunan, namun meningkat kembali pada hari ke-9 sampai hari ke-17. Pra-pendingin dalam masa simpan yang terbaik yaitu perlakuan prapendinginan 15 menit yang memiliki daya simpan selama 17 hari dalam suhu ruang. Menurut Pantastico, (1986) pengemasan hasil pertanian segar mempunyai pengaruh terhadap kandungan gizi komoditinya. Vitamin $\mathrm{C}$ cukup stabil dalam keadaan kering, tetapi dalam keadaan larut mudah rusak karena bersentuhan dengan udara terutama bila terkena panas Almatsier, (2002). Kandungan gula dan vitamin-vitamin lebih dapat dipertahankan menggunakan pra-pendiginan. Kandungan vitamin $\mathrm{C}$ buah tomat selama penyimpanan, menunjukkan bahwa vitamin $\mathrm{C}$ mengalami peningkatan sampai hari ke-5 dan ke-7 penyimpanan kemudian mengalami penigkatan kembali pada hari ke-9 dalam masa simpan. kandungan vitamin $\mathrm{C}$ yang diukur sebagai asam askorbat, setiap perlakuan konsentrasi gelatin dan konsentrasi asam sitrat serta interaksinya menunjukkan adanya pengaruh yang nyata terhadap kandungan vitamin $\mathrm{C}$ buah tomat. Dengan semakin tingginya konsentrasi gelatin dan konsentrasi asam sitrat maka kandungan asam askorbat buah tomat adalah makin tinggi. Edible coating membatasi keluar masuknya $\mathrm{O}_{2}$ ke dalam jaringan buah. Tannenbaum, (1976) menyatakan bahwa pengurangan $\mathrm{O}_{2}$ akan menghambat degdradasi asam askorbat menjadi asam dehidroaskorbat dan $\mathrm{H}_{2} \mathrm{O}_{2} \cdot \mathrm{H}_{2} \mathrm{O}_{2}$ yang dihasilkan dapat menyebabkan autooksidasi sehingga akan memperbesar kerusakan vitamin C.

\section{Susut Bobot (\%)}

Berdasarkan uji nilai tengah susut bobot buah tomat dilakukan setelah pemanenan. Kehilangan bobot ini sangat merugikan secara ekonomi, terutama bagi sayuran yang dijual berdasarkan beratnya. Susut bobot dapat diartikan sebagai kehilangan kandungan air. Susut bobot telah terjadi pada saat sebelum dipanen, tetapi dapat diperoleh kembali pada saat malam hari dimana tanaman dapat mengganti kehilangan air melalui proses penyerapan air dari dalam tanah.

Tabel 3. Nilai Persentase Susut Bobot (\%)Buah Tomat.

\begin{tabular}{ccccccccccc}
\hline \multirow{2}{*}{ Perlakuan $^{(\mathrm{x})}$} & \multicolumn{8}{c}{ Pengamatan Susut Bobot \% (Hari) } \\
\cline { 2 - 11 } & 1 & 3 & 5 & 7 & 9 & 11 & 13 & 15 & 17 \\
\hline P0 & $1,33^{\mathrm{a}}$ & $2,31^{\mathrm{a}}$ & $3,41^{\mathrm{a}}$ & 4,13 & 4,94 & & & \\
\hline P15 & $1,31^{\mathrm{a}}$ & $2,25^{\mathrm{a}}$ & $3,46^{\mathrm{a}}$ & 4,23 & 5,11 & 6,18 & 7,12 & 7,96 \\
\hline P30 & $1,78^{\mathrm{a}}$ & $3,34^{\mathrm{b}}$ & $5,47^{\mathrm{a}}$ & & & & & \\
\hline P45 & $2,32^{\mathrm{b}}$ & $4,11^{\mathrm{b}}$ & & & & & & \\
\hline
\end{tabular}

Keterangan :

(x) $\mathrm{P} 0=$ Tanpa pra-pendinginan, $\mathrm{P} 15=$ Pra-pendinginan 15 menit, $\mathrm{P} 30=$ Pra-pendinginan 30 menit, dan P45= Pra-pendinginan 45 menit. Superscript yang diikuti oleh huruf yang sama menunjukkan tidak berbeda nyata, dimana pada baris yang kosong pada Tabel 3 ini buah tomat telah membusuk dan tidak dapat diamati atau dianalisis 
Kehilangan air tersebut dapat mempengaruhi penampakan tekstur dan nilai gizi buah. Berdasarkan analisis menunjukan bahwa perlakuan pra-pendinginan berbeda nyata terhadap susut bobot buah tomat. Susut bobot pada hari ke-3,ke-5 dan ke-7 dalam setiap perlakuan pra-pendinginan berbeda nyata dengan perlakuan lainnya. Secara umum perbedaan juga terjadi pada hari penyimpanan yang lainnya dibuktikan dengan adanya notasi superscript yang berbeda. Menurut Pantastico, (1986), buah tomat yang diberi pra-pendinginan bahwa kehilangan bobot akibat kegiatan fisiologis dapat dipertahankan sampai $2,9 \%$. Data hasil pengukuran susut bobot dapat dilihat pada Tabel 3

Pada Tabel 4 menunjukan bahwa perlakuan pra-pendinginan dapat diketahui kadar total asam buah tomat setiap perlakuan mengalami peningkatan dan penurunan dengan semakin meningkatnya suhu pra-pendinginan dan lama penyimpanan, hasil analisis total asam buah tomat pada hari pengamatan tidak memberikan pengaruh yang nyata, namun pengamatan pada hari ke-7 perlakuan tanpa prapendinginan tidak berbeda nyata dengan perlakuan pra-pendinginan 15 menit dan perlakuan tanpa pra-pendinginan, pra- pendinginan 15 menit berbeda nyata dengan pra-pendinginan 30 menit. Hasil uji nilai tengah yang paling tinggi pada hari ke-3 yaitu perlakuan pra-pendinginan 15 menit dengan nilai $5,28 \%$, berdasarkan pra-pendinginan masing-masing perlakuan dalam masa simpan, hal ini menunjukan nilai total asam selama penyimpanan dari hari ke-1 sampai ke-17 mengalami kenaikan dan penurunan. Setiap perlakuan pra-pendinginan nilainya pun semakin tinggi dan ada yang semakin rendah. Masa simpan yang baik terdapat pada perlakuan pra-pendinginan yaitu pra-pendinginan 15 menit mencapai 17 hari.

Artinya dengan semakin lama pra-pendinginan maka akan mempengaruhi penurunan dan kenaikan total asam pada buah tomat setiap perlakuan.

\section{Total Padatan Terlarut (TPT) \% Brix}

Menurut Sjaifullah, (1996) kandungan total padatan terlarut dapat menunjukkan derajat kematangan. Kadar gula meningkat sejalan dengan proses pematangan. Kandungan total padatan terlarut (TPT) pada suatu bahan menunjukkan kandungan gula yang terdapat pada bahan tersebut.

Tabel 4. Nilai Persentase Total Asam (\%) Buah Tomat.

\begin{tabular}{ccccccccccc}
\hline \multirow{2}{*}{ Perlakuan $^{(\mathrm{x})}$} & \multicolumn{8}{c}{ Pengamatan Total Asam \% (Hari) } \\
\cline { 2 - 10 } & 1 & 3 & 5 & 7 & 9 & 11 & 13 & 15 & 17 \\
\hline P0 & 5,12 & 4,80 & 4,80 & $4,64^{\mathrm{b}}$ & 4,32 & 3,04 & & & \\
P15 & 4,80 & 5,28 & 4,96 & $4,48^{\mathrm{b}}$ & 3,20 & 3,68 & 4,48 & 4,32 & 4,00 \\
P30 & 4,80 & 4,64 & 4,64 & $3,53^{\mathrm{a}}$ & & & & & \\
P45 & 4,80 & 4,48 & 5,28 & & & & & & \\
\hline
\end{tabular}

Keterangan :

(x) $\mathrm{P} 0=$ Tanpa pra-pendinginan, $\mathrm{P} 15=$ Pra-pendinginan 15 menit, $\mathrm{P} 30=$ Pra-pendinginan 30 menit, dan P45= Pra-pendinginan 45 menit. Superscript yang diikuti oleh huruf yang sama menunjukkan tidak berbeda nyata, dimana pada baris yang kosong pada Tabel 4 ini buah tomat telah membusuk dan tidak dapat diamati atau dianalisis. 
Tabel 5. Nilai Persentase Total Padatan Terlarut Buah Tomat.

\begin{tabular}{ccccccccccc}
\hline \multirow{2}{*}{ Perlakuan $^{(\mathrm{x})}$} & \multicolumn{8}{c}{ Pengamatan Total Padatan Terlarut } \\
\cline { 2 - 11 } & 1 & 3 & 5 & 7 & 9 & 11 & 13 & 15 & 17 \\
\hline P0 & 5,15 & 4,12 & 4,20 & 3,70 & 4,33 & 3,90 & & & \\
\hline P15 & 4,95 & 3,82 & 4,07 & 3,90 & 4,00 & 3,95 & 3,63 & 3,03 & 3,35 \\
\hline P30 & 5,05 & 3,60 & 4,28 & 3,95 & & & & & \\
\hline P45 & 5,02 & 3,68 & 4,32 & & & & & & \\
\hline
\end{tabular}

Keterangan :

(x) $\mathrm{P} 0=$ Tanpa pra-pendinginan, $\mathrm{P} 15=$ Pra-pendinginan 15 menit, $\mathrm{P} 30=$ Pra-pendinginan 30 menit, dan P45= Pra-pendinginan 45 menit. Perubahan kandungan Total Padatan Terlarut pada buah tomat setiap perlakuan, dimana pada baris yang kosong pada Tabel 5 ini buah tomat telah membusuk dan tidak dapat diamati atau dianalisis

Peningkatan kandungan total padatan terlarut dipengaruhi oleh peningkatan laju respirasi. Pada saat respirasi, terjadi pemecahan oksidatif dari bahan-bahan yang kompleks, seperti karbohidrat, lemak, dan protein. Laju respirasi tomat dipengaruhi oleh kondisi tomat itu sendiri (cacat atau sempurna) dan kondisi lingkungannya. Keadaan tomat yang cacat dapat mempercepat laju respirasi tomat tersebut, sehingga akan mempengaruhi penampakan luar dan dalam tomat

Analisis Total Padatan Terlarut (TPT) pada buah tomat menunjukkan nilai kemanisan (total gula). Semakin tinggi nilai TPT, semakin manis rasa buah tomat tersebut. Semakin tinggi nilai padatan terlarut, semakin tinggi kandungan sukrosa buah. Kandungan padatan terlarut dinyatakan dalam \% brix sebagai ukuran mengetahui tingkat manis buah tomat. Perlakuan pra-pendinginan dapat memperpanjang masa simpan, mulai hari ke-1 sampai hari ke-17 kandungan TPT tidak berbeda nyata antara perlakuan pra-pendinginan buah tomat. Perlakuan pra-pendinginan meningkatkan dan menurunkan kandungan total padatan terlarut karena selama perlakuan dingin aktivitas enzim hidrolisis menurun, tetapi begitu suhu normal kembali terjadi lonjakan aktivitasnya. Hal ini yang menyebabkan hidrolisis pati meningkat, yang menyebabkan peningkatan kandungan padatan terlarut. Menurut Tawali et al, (2004) pada penyimpanan buah tomat, setiap kenaikan suhu $15^{\circ} \mathrm{C}$ akan menyebabkan kenaikan reaksi kimia buah menjadi dua kali lipat. Pada penelitian ini menunjukkan bahwa perlakuan pra-pendinginan tidak berpengaruh pada kandungan asam buah. Hasil analisis uji nilai tengah menunjukan bahwa tidak ada interaksi antara perlakuan prapendinginan dan konsentrasi etilen dalam masa simpan terhadap perubahan TPT pada buah tomat yang diamati. Buah tomat adalah buah klimaterik sehingga pemberian etilen tidak akan meningkatkan laju respirasi secara drastis, dari perlakuan pra-pendinginan hasil daya simpan yang baik pada perlakuan pra-pendinginan $15^{\circ} \mathrm{C}$ 

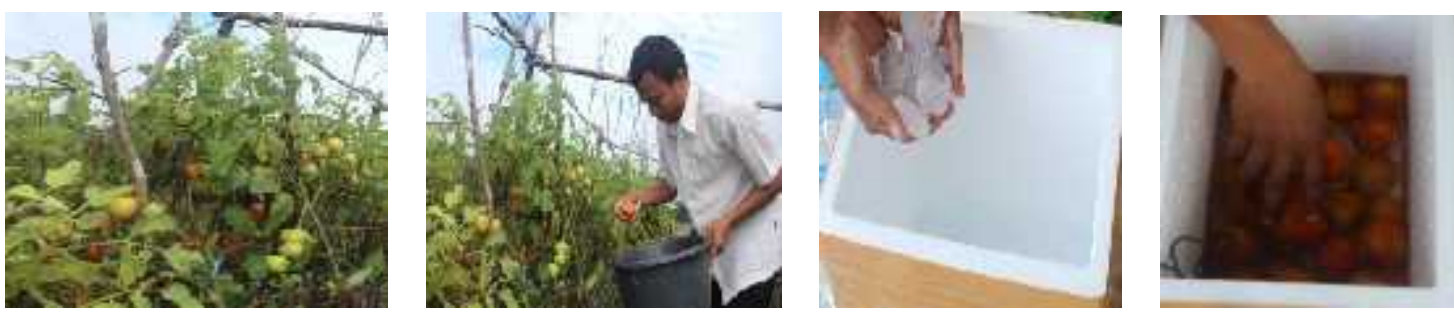

Keterangan : (a) tanaman buah tomat, (b) panen buah tomat, (c) pemberian es batu dengan air aqudes, (d) perendaman buah tomat setiap perlakuan P0, P15, P30, dan P45.

Gambar 1. Pengambilan Sampel dan Pelaksanan Perlakuan Buah Tomat (Slanum lycopersicum l)
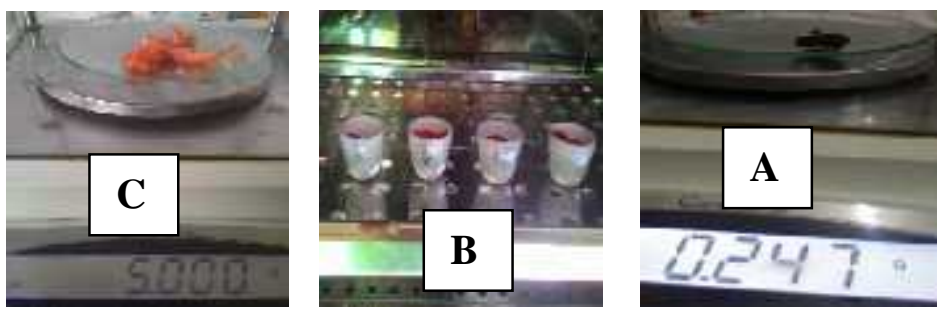

Keterangan : (a) penimbangan buah tomat, (b) buah tomat yang sudah ditimbang di oven selama 6 jam, (c) penimbangan buah tomat yang sudah di oven.

Gambar 2. Pengamatan Kadar Air (\%)Buah Tomat (Slanum lycopersicum l)
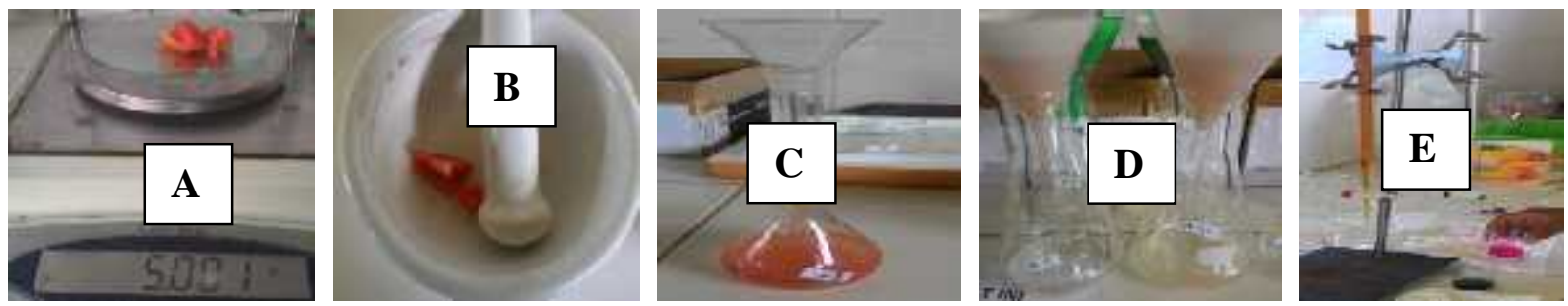

Keterangan : (a) penimbangan buah tomat, (b) penggerusan buah tomat, (c) pengenceran dan pencampuran cairan buah tomat, (d) penyaringan cairan buah tomat, (e) titrasi vitamin $\mathrm{C}$ dan total asam.

Gambar 3. Pengamatan Vitamin C (mg/100g) dan Total Asam (\%)

Buah Tomat (Slanum lycopersicum l)
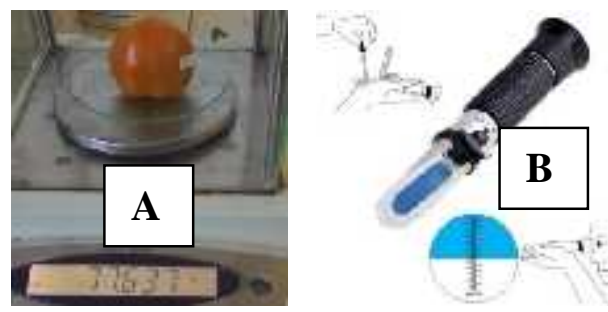

Keterangan : (a) penimbangan susut bobot buah tomat, (b) proses analisis total padatan terlarut buah tomat dengan menggunakan alat refraktometer.

Gambar 4. Pengamatan Total Padatan Terlarut (\% Brix) dan Susut Bobot (\%) 


\section{KESIMPULAN}

Berdasarkan hasil dan pembahasan pada penelitian yang dilakukan maka dapat disimpulkan sebagai berikut :

1. Perlakuan pra-pendinginan berpengaruh nyata terhadap kadar air, vitamin $\mathrm{C}$, susut bobot, dan total asam buah tomat selama masa simpan.

2. Hasil tertinggi selama penyimpanan terdapat pada pra-pendinginan 15 menit dengan nilai yaitu: kadar air 95,48 \%, vitamin C 005 $\mathrm{mg} / 100 \mathrm{~g}$, susut bobot $7,96 \%$, total asam $5,28 \%$, dan total padatan terlarut 4,95 $\%$ brix.

3. Perlakuan pra-pendinginan yang terbaik dan mampu mempertahankan kadar air, vitamin $\mathrm{C}$, susut bobot, total asam, dan total padatan terlarut adalah prapendinginan 15 menit dengan lama penyimpanan sampai 17 hari.

\section{DAFTAR PUSTAKA}

Almatsier, S. 2002. Prinsip Dasar Ilmu Gizi. Gramedia. Jakarta.

Cahyaningsih, S. 2002. Aspek Pra-pendinginan Dan Suhu Penyimpanan Terhadap Kesegaran Bunga Lili (Lilium sp) Potong. Bogor: FPIPB.

Kader, A.A. 1992. Postharvest Technology of Holticultura Crops. California: University of California USA.

Pantastico, E.R. 1989. Fisiologi Pasca Panen, Penanganan dan Pemanfaatan Buahbuahan dan Sayur-sayuran Tropika dan Subtropika. Gadjah Mada University Press, Yogyakarta.

Syaifullah, 1996. Petunjuk Pemilihan Buah Segar. Penebar Swadaya. Jakarta.
Tannenbaum, S.R. 1976. Vitamin and Minerals in Fennema O.R. (Ed). Principles of Food Science. Part I: Food Chemistry. P.347-384. Marcel Dekker, Inc. New York.

Tawali, Abu Bakar et al. (2004). Pengaruh Suhu Penyimpanan terhadap Mutu Buah-Buahan Impor yang Dipasarkan di Sulawasi Selatan. Makassar: Universitas Hassanuddin.

Wills, R H.H., Lee, T.H., Graham, D., Mc. Glasson, W.B. and E.G. Hall. 1998. Postharvest. An. Introduction to the Physiology and Handlingh of Fruit and Vegetables. New South Wales University Press Ltd., Kensington : 105-107.

Winarno, F.G. 2002. Fisiologi Lepas Panen Produk Hortikultura. M_Brio Press. Bogor.

Winarno, F.G. dan Aman, W. 1981. Fisiologi Lepas Panen. Sastra Budaya. Jakarta. 